\title{
IMPLEMENTASI PAKET VII KEBIJAKAN EKONOMI PEMBANGUNAN DENGAN SATU PEMANFAATAN RUANG DAN PENGGUNAAN LAHAN DI INDONESIA
}

\author{
Bono Prambudi \\ STIE Muhammadiyah Jakarta, bprambudi@yahoo.com
}

\begin{abstract}
ABSTRAK
Pembangunan merupakan suatu kegiatan yang sangat penting dalam upaya peningkatan pertumbuhan ekonomi bagi Indonesia. Sehingga, kebijakan ekonomi yang diambil Pemerintah harus bisa mendorong, berkesinambungan dan saling berkaitan antar satu sektor ekonomi dengan sektor yang lainya demi mencapai tujuan yang diharapkan.Kebijakan otonomi daerah diharapkan mampu mereduksi hal ini demi kesejahtraan bersama, atara pusat dan daerah masingmasing.Penelitian ini mengupas bahwa penetapan RTRW (Rencana Tata Ruang dan Wilayah) merupakan suatau hal yang harus disepakati bersama demi merumuskan pembangunan ekonomi nasional.
\end{abstract}

Kata Kunci: Kebijakan, pembangunan dan RTRW

\section{ABSTRACT}

Development is a very important activity in efforts to increase economic growth for Indonesia. Thus, the economic policies taken by the Government must be able to encourage, be sustainable and interrelated between one economic sector with the other sectors in order to achieve the expected goals. The regional autonomy policy is expected to be able to reduce this for the sake of shared prosperity, between the center and the respective regions. This study examines that the determination of the RTRW (Spatial and Regional Plan) is a matter that must be mutually agreed upon in order to formulate national economic development.

Keywords: Policy, Development and RTRW

\section{PENDAHULUAN}

Perubahan sistem pemerintahan ke arah demokrasi memberikan ruang otonomi kepada daerah dalam pengelolaan wilayah. Hal ini menjadi dasar Penyelenggaraan Pemerintah Daerah. Berlandaskan Undang-Undang No.32 Tahun 2004 Tentang Pemerintahan Daerah memberikan pengaruh pada kewenangan dan kewajiban pemerintah daerah secara mandiri untuk mengurus rumah tangganya sendiri dengan landasan Pasal 18 Undang-Undang Dasar 1945. Termasuk dalam kewenangannya mengatur tata ruang wilayah di daerah. Peranan pemerintah daerah serta masyarakat dalam perencanaan dan pelaksanaan penataan ruang, sangat menentukan terhadap partumbuhan kota. Hal tersebut berkaitan dengan pembangunan daerah baik perkotaan hingga pedesaan yang belum dibangun maupun yang sudah dibangun. Ini sangat mempengaruhi pada pengembangan wilayah untuk lokasi industrialisasi pembangunan, berbagai kompleks perumahan dan pemukiman baru muncul pusat perdagangan barang dan jasa perbankan, dan perkotaan, pendidikan dan rekreasi, transportasi. Bahkan sebuah wilayah akan mengalami perkembangan dari sebuah desa menjadi sebuah kota dan siklusnya terus menerus bergerak berkembang dengan sendirinya. 
Pertumbuhan wilayah bisa dipengaruhi oleh meningkatnya jumlah penduduk hingga berkembang dari sebuah wilayah kecil atau pedesaan menjadi sebuah wilayah luas dengan segala fasilitas yang ada atau disebut perkotaan. Timbulnya permasalah di perkotaan seperti perebutan ruang wilayah kota yang semakin keras, penggusuran pemukiman meningkat, dan peralihan pemanfaatan ruang ruang di perkotaan semakin sulit dikendalikan.

Indikasi ini mengartikan bahwa pelaksanaan, pendayagunaan sumber daya alam, sumber daya manusia dan sumber daya buatan sebagai pokok-pokok kemakmuran rakyat perlu dilakukan secara terencana dan terpadu, rasional, optimal, bertanggung jawab dan sesuai dengan pengelolaan lingkungan hidup. Serta kualitas tata ruang dalam proses perencanaannya perlu di perhitungkan dalam rangka pelestarian fungsi dan kemampuan lingkungan hidup bagi pembangunan yang berkelanjutan. Dengan demikian perencanaan tata ruang mestinya berkaitan dengan upaya peman-faatan sumber daya alam secara efisiensi dan efektif, serta perlu alokasi ruang untuk kegiatan yang sesuai dengan daya dukung lingkungan alam dengan memperhatikan sumber daya manusia serta aspirasi masyarakat. Apabila pemanfaatan ruang tidak dilakukan penataan dengan baik, kemungkinan akan terjadi pemborosan pemanfaatan ruang dan penurunan kualitas ruang kehidupan. Maka perlu penataan ruang sesuai dengan kegiatan, fungsi lokasi, kualitas ruang dan estetika lingkungan. Karena keterbatasan ruang dalam pertumbuhan kota akan menyebabkan timbulnya perebutan dalam memanfaatkan ruang dan penggunaan tanah yang dianggap strategi sehubungan dengan pemanfaatan ruang dan penggunaan tanah yang bernilai atau mengun-tungkan secara ekonomis, atau terletak pada lokasi dan jalur perhubungan yang menguntungkan. Dalam pelaksanaan undang-undang dalam penataan ruang tidak saja dalam tahap perencanaan, tetapi juga diikuti dengan pelaksanaan pemanfaatan ruang yang sesuai dengan zona-zona pemanfaatan ruang yang telah ditetapkan dalam perencanaan tata ruang. Disini penataan ruang di perlukan law enforcement undang-undang penataan ruang yaitu perlunya penyebaran dalam berbagai ketentuan operasional untuk menghindari konflik. Karena peraturan perundang-undangan lain juga belum tentu sinkron atau mudah disinkronkan bahkan bertentangan. Disamping adanya penafsiran yang berbeda dari peraturan yang sama, serta mekanisme pemantauan dan pengendalian yang belum mantap disamping dari manusianya baik masyarakat maupun aparat pemerintah yang masih terbatas pengetahuannya dan kesadarannya untuk mentaati peraturan (Didik Suhariyanto, 2009:1).

Berkaitan dengan fenomena ini akhirnya Pemerintah merilis kebijakan untuk menjadi solusi yang terbaik dalam menjawab permasalah yang terjadi dilapangan disebut "Paket VIII Kebijakan Ekonomi" Pengumuman Paket Kebijakan Ekonomi VIII dirilis pada hari Senin tanggal 12 Desember 2015 di Istana Kepresidenan, Jakarta. Paket Kebijakan kali ini meliputi tiga hal pokok, yaitu kebijakan satu peta nasional (one map policy) dengan skala 1:50.000, membangun ketahanan energi melalui percepatan pembangunan dan pengembangan kilang minyak di dalam negeri, dan insentif bagi perusahaan jasa pemeliharaan pesawat (maintenance, repair and overhoul/MRO).

Berdasarkan pada uraian latar belakang pemikiran tentang peranan pemerintah dalam pengelolaan tata ruang wilayah maka penelitian ini ingin mengkaji pengembagan pengelolaan wilayah melalui implementasi Paket VIII Kebijakan Ekonomi Pembangunan Dengan Satu Pemanfaatan Ruang dan Penggunaan Lahandi Indonesia.

\section{KAJIAN LITERATUR}

\section{Kebijakan Satu Peta}

Menteri Koordinator Bidang Prekonomian menyatakan bahwa Paket Kebijakan Ekonomi VIII menyatakan, pengembangan kawasan atau infrastruktur, seringkali terbentur dengan sejumlah masalah terkait pemanfaatan ruang dan penggunaan lahan. Konflik ini sulit diselesaikan karena Informasi Geospasial Tematik (IGT) saling tumpang tindih satu wilayah dengan wilayah lain. Oleh sebab itu, kebijakan satu peta yang mengacu pada satu referensi geospasial, satu standar, satu basis data dan satu geoportal untuk mempercepat pelaksanaan pembangunan 
nasional menjadi salah satu prioritas Pemerintah. Basis referensi peta yang sama, juga akan meningkatkan keadalan informasi terkait lokasi dari berbagai aktivitas ekonomi. Ini akan memberikan kepastian usaha. Berbagai informasi yang dikompilasi dalam satu peta ini juga bisa dimanfaatkan untuk sejumlah simulasi, antara lain untuk mitigasi bencana.

Melalui Peraturan Presiden (Perpres) tentang Percepatan Pelaksanaan Kebijakan Satu Peta ini, kementrian dan lembaga akan menyiapkan peta tematik skala 1:50.000 sesuai rencana aksi masing-masing dengan batas akhir tahun 2019.Kebijakan ini akan mempermudah mempercepat penyelesaian konflik tumpang tindih pemanfaatan lahan, penyelesaian batas wilayah seluruh Indonesia (www.Kementerian PPN_Bappenas Berita paket 8.htm).

\section{Beberapa Studi Kasus di Indonesia}

Menurut Undang-Undang Nomor 26 Pasal 1 Tahun 2007 menyatakan bahwa ruang adalah wadah yang meliputi ruang daratan, ruang lautan, dan ruang udara, sebagai satu kesatuan dalam sebuah wilayah, tempat manusia dan makhluk hidup lainnya yang ada didalamnya melakukan aktivitas serta memelihara kelangsungan kehidupannya. Berkaitan dengan hal ini Nandang Najmulmunir (2013:213-220) melakukan penelitian berkaitan dengan penataan ruang meliputi perencanaan, pemanfaatan ruang dan pengendaliannya, diproses oleh pemerintah Kabupaten Bekasi mulai dari draft rencana tata ruang sampai menjadi dokumen kebijakan tata ruang. Kebijakan tersebut mengarhkan aktivitas masyarakat agar menempati ruang yang terencana dengan tujuan terencana pula. Partisipasi masyarakat dalam proses perencanaan memberikan pengaruh yang besar terhadap efektivitas kebijakan yang di keluarkan oleh Pemerintah Kabupaten Bekasi.

Partisipasi dalam perencanaan menggambarkan berjalannya komunikasi masyarakat dengan penyusun kebijakanpublik. Dengan adanya komunikasi ini maka secara langsung dapat memberikan kontribusipada proses, mekanisme pemanfaatan dan pengendalian ruang, sehingga kebijakanRTRWK akan mencapai sasaran secara efektif. Partisipasi dalam pemanfaatan ruang memiliki pengaruh cukup besar terhadap efektivitas kebijakan RTRWK. Namunpengaruh langsungnya relatif kecil, sedangkan pengaruh tak langsung palingbesar, khususnya pada peningkatan partisipasi dalam perencanaan. Partisipasi masyarakat dalam pengawasan berpengaruh paling kecilterhadap efektivitas kebijakan RTRWK.Pengaruh langsungnya hampir sebandingdengan pengaruh tak langsung, yaitu padapartisipasi dalam perencanaan. Sedangkanpengaruh tak langsung pada partisipasimasyarakat dalam pemanfaatan sangat kecil. Partisipasi masyarakat dalamperencanaan kebijakan tata ruang wilayah kabupaten sangat penting karena menjadidasar efektivitas dalam implementasinya, serta menjadi hulu dari partisipasi masyarakatdalam pemanfaatan dan pengawasan.

Dinamika pembangunan Kota Semarang telah menunjukkan banyak kemajuan yang pesat. Hal ini dapat dilihat daripertumbuhan ekonomi yang relatif stabil yang didukung dengan iklim investasi kondusif dan stabilitas politik dankeamanan yang terjaga telah berhasil mendorong perkembangan sektor industri, perdagangan dan jasa sebagailokomotif perekonomian Kota Semarang. Namun demikian pencapaian semacam ini belum sepenuhnya mampumengatasi sejumlah permasalahan klasik maupun mengantisipasi kerusakan lingkungan. Banjir limpasan air laut(rob), penurunan kualitas udara dan air, kesemrawutan lalu-lintas, dan tingginya migrasi masuk penduduk (inmigration)masih terus terjadi. Secara kontradiktif kecenderungan pembangunan tata ruang Kota Semarang belummampu memenuhi ketentuan undang-undang. RTRW belum dapat berperan efektif sebagai instrumen pengendalipembangunan Kota Semarang. Oleh karena itu dilakukan penelitian dengan tujuan mengetahui kebijakanpembangunan terhadap perubahan tata ruang di Kota Semarang. Terdapat korelasi antara kebijakan dan peraturantata ruang yang telah ditetapkan terhadap munculnya beberapa permasalahan atau perubahan tata ruang di KotaSemarang. Korelasi kedua hal tersebut tentu saja dipengaruhi oleh banyak faktor seperti proses perumusankebijakan yang sebagian tidak dilakukan secara komprehensif dan baik, kurangnya sosialisasi kebijakan kepadamasyarakat, implementasi yang kurang optimal dan lain-lain (Nugroho dan Sugiri,2009:41-51). 
Sedangkan penelitian yang dilakukan oleh Suardi, dkk (2013:13-22), melihat penataan RTRW di 2 Kecamatan Gayamsari dan Kecamatan Sememarang Timur kebutuhan yang semakin mendesak sejalan dengan tingkat perkembangan kota-kota di Wilayah Jawa Tengah khususnya Kota Semarang untuk dapat mengefektifkan pelaksanaanya, diperlukan suatu aturan pola pemanfaatan ruang (Zoning Regulation) sebagai alat operasional rencanan tata ruang. Berdasarkan kenyataan tersebut, untuk melaksanakan pembangunan kota yang lebih harmonis dan mampu mengatisipasi berbagai dampak yang ditimbulkan, terutama pada wilayah kota sedang, wilayah kota besar, dan wilayah kota metropolitan, maka Pemerintah Daerah telah menyususn aturan pola pemanfaatan ruang kawasan wilayah kota (zoning regulasi).Untuk memaksimalkan kegiatan tersebut, tentu perlu diketahui sejauh mana Aturan Pola PemanfaatanRuang tersebut dapat mengontrol setiap pembangunan atau pemanfaatan lahan di wilayah yang bersangkutan. Seperti halnya dalam penelitian ini, untuk mengetahui hal tersebut pada wilayah Kecamatan Semarang Timurdan Kecamatan Gayamsari perlu dilakukan evaluasi dengan cara membandingkan Penggunaan Lahan tahun2007 di daerah yang bersangkutan dengan Rencana Tata Ruang tahun 2000-2010 yang berlaku agar diketahui seberapa besar kesesuaiannya. Penggunaan Lahan tahun 2007 dalam penelitian ini diperoleh dari hasil digitasi citra satelit Ikonostahun 2007, sedangkan Rencana Tata Ruang Wilayah (RTRW) tahun 20002010 diperoleh dari instansi terkait.Hasil yang diperoleh setelah melakukan pengolahan citra dan perbandingan data, besarnya kesesuaian antara penggunaan lahan tahun 2007 dengan RTRW tahun 2000 - 2007 di daerah penelitian lebih tinggi terdapat padaKecamatan Semarang Timur dengan persentase kesesuaian $82,686 \%$, Sedangkan pada Kecamatan Gayamsarisebesar $63,013 \%$.

Selanjutnya, penelitian yang dilakukan oleh Zaid (2013:1488-1500) bahwa untuk mengetahui seberapa signifikan pengaruh tata ruang kantorterhadap produktivitas kerja pegawai di PKP2A III LAN Samarinda. Metodologipenelitian yaitu Kuantitatif Verifikatif. Teknik pengumpulan data dengan libraryresearch (telaah kepustakaan) dan field work research (telaah di lapangan) yangterdiri dari observasi, wawancara, angket, dan penelusuran dokumen. Teknikanalisis data yaitu statistik parametrik yang bertujuan untuk mengukur seberapasignifikan pengaruh tata ruang kantor terhadap produktivitas kerja pegawai yangdimulai dengan mencari koefisien korelasi (hubungan) dengan rumus KoefisienKorelasi Product Moment dan tingkat kesalahan yang dipilih adalah 5\%, analisisregresi linier sederhana, dan koefisien determinasi (pengaruh). Kesimpulannya, dalam penelitian ini dapat diketahui bahwa terdapat pengaruh yang signifikandari tata ruang kantor terhadap produktivitas kerja pegawai di PKP2A III LANSamarinda.

Penelitian yang dilakukan oleh Jeky El Boru (2013:255-266), dalam penelitian ini dilakukan untuk menganalisis pengaruh pembangunan Jalan Layang Janti terhadap perkembangan tata ruang kawasan Janti, meliputi ruang terbangun, ruang terbuka, serta hubungan antar ruang atau Linkage. Metode pengumpulan data dilakukan melalui observasi, pengamatan foto udara, wawancara, sedangkan metode analisis melalui deskripsi secara kualitatif yang berupa "superimposed method" dari dua lapisan kondisi lahan, yaitu kondisi tata ruang sebelum dan sesudah pembangunan jalan layang. Hasil penelitian menunjukkan bahwa pengaruh pembangunan Jalan Layang Janti terdapat pada massa bangunan ("solid"), pertambahan ruang terbuka yang berupa jaringan jalan, parkir, dan taman, sedangkan pada hubungan antar ruangsecara visual dan struktural-yakni tumbuhnya bangunan dangan bentuk dan gaya baru, sehingga bentuk tampilan bangunan secara keseluruhan tidak proposional. Pada hubungan kolektif, Jalan Janti semakin kuat perannya sebagai kerangka utama jaringan jalan.

Selanjutnya, penelitian yang dilakukan oleh Rizka Maria dan Hilda Lestiana (2014:77-89) di wilayah Sub DAS Cikapundung merupakan kawasan potensial yang berfungsi sebagaidrainase utama dan penyedia air baku untukkebutuhan penduduk di Kota Bandung.Peningkatan lahan terbangun di wilayah inimengakibatkan banyaknya konversi lahan yangmemperluas permukaan kedap air yangmenyebabkan berkurangnya infiltrasi menurunnya pasokan airtanah dan meningkatnyalimpasan permukaan. Untuk mengetahuipengaruh penggunaan lahan terhadap fungsikonservasi airtanah maka dilakukan analisisindeks konservasi. Metode yang 
dilakukanadalah memberikan bobot pada parameter jenisbatuan, jenis tanah, morfologi, curah hujan danpenggunaan lahan yang masing-masing telah dinilai sesuai pengaruhnya pada kemampuan untukmenyerap air hujan. Dari analisis tersebutdiketahui bahwa perubahan penggunaan lahanpada kurun waktu 2001 - 2008 telah menurunkanfungsi konservasi secara keseluruhan pada SubDAS Cikapundung. Nilai fungsi konservasi mulaimenurun ditunjukkan oleh pengurangan kelasyang bernilai konservasi baik seluas 5080,5 ha. Namun kondisi ini juga diikuti dengan kenaikankelas konservasi normal seluas 5093,3 ha danpenurunan kelas konservasi kritis seluas 12,9 ha.

Penelitian yang dilakukan oleh Siti Aminah (2015:59-79), dengan merumuskan dua hal. Pertama, permasalahan praktik penataan ruang di perkotaan, khususnya di Surabaya, yang telah menimbulkan kontestasi dan konflikdengan melibatkan aktor pemerintah, masyarakat, dan kekuatan kapitalis/investor. Kedua, kerangka penataan ruang yang menggunakan Perda RTRW No. 3 Tahun 2007 telahmenimbulkan dampak yang berujung pada penguatan dan keberpihakan pemerintahkota kepada pihak kapitalis/investor. Kedua hal tersebut dianalisis dengan menggunakanpendekatan sosio-spasial. Penelitian dilakukan dengan menggunakan pendekatankualitatif dan analisis deskriptif. Problematika praktik tata ruang yang ada di Surabayamerupakan indikasi dari transformasi dalam proses penataan ruang di mana ruangbukan hanya diproduksi dan direproduksi untuk kepentingan klas kapitalis, melainkanjuga ruang direstrukturisasi dengan cara mengubah fungsi ruang dan diperuntukkanuntuk publik. Hal ini relevan dengan perkembangan kajian penataan ruang mutakhiryang menunjukkan bahwa praktik penataan ruang di perkotaan merupakan ref leksi darikondisi sosial, ekonomi, dan politik. Selain itu, ruang diproduksi dalam modus produksikapitalis dan ekspresi ruang kota merupakan dialektika antara produksi, konsumsi, danadministrasi (perencanaan dan implementasi kebijakan).

Akhirnya penataan ruang memiliki berbagi permasalah tidak hanya ruang wilayah bagi perkembangan pedesaan menjadi sebuah wilayah perkotaan. Sebab semuanya akan bermuara kepada wilayah yang cukup luas menjadi daerah maju yang disebut perkotaan. Perkotaan merupakan sebuah tempat terjadinya pluralisme budaya, dimana pergerakan penduduknya yang memiliki latar budaya yang saling berbeda adalah hal yang kerap memicu terjadinya kontradiksi serta kompleksitas bagi kehidupan di wilayah perkotaan. Berbagai komunitas yang sailing menunjukan jati diri dengan keinginan yang tetap mempertahankan budaya aslinya, dimana hal ini merupakan hal yang berkaitan dengan dinamika perkembangan wilayah. Penduduk wilayah perkotaan selalu berubah dan bergerakn sesuai dengan tingkat kebutuhan hidupnya seta upaya penyesuaian terhadap lingkungan binaanya, yang mana jika dikaitkan dengan kebutuhan akan ruangnya pun akan berubah pula. Semakin tinggi tingkat persaingan untuk memperoleh kesempatan berusaha semakin luas pergerakan serta jaringan yang terjadi.

Terjadinya perubahan wilayah perkotaan disimpulkan bahwasanya dalam penataan ruang yang sangat berkaitan erat sebagai bagian dari akibat dari pertubuhan sistem pengelolaan wilayah perkotaan yang dirasakan masih sangat kurang dalam pengawasan pembangunan serta implementasi penerapan kebijakan dilapangan yang masih memerlukan pemahaman yang mendalam dari penghuni wilayah Perkotaan.Peran Pemerintah harus lebih demokrasi dalam menyikapi penataa ruang yang dalamnya banyak kepentingan secara politik. Sehingga Penataan ruang harus benar-benar diperhatikan disesuaikan dengan kearifan budaya lokal walaupun harus memperhatikan kesejahtraan masyarakat (Tusin ,2004:46-59).

Semua penelitian data menunjukan bahwa sangat penting pengelolaan ruang dengan memperhatikan keberadaan lingkungan sekitarnya dengan memanfaatkan fungsi yang dimiliki. Ternyata tata ruang juga bisa mempengaruhi kinerja sebuah wilayah dalam meningkatkan kualitas dan kuantitas produksi wilayahnya untuk menjadi lebih baik dari tahun sebelumnya. Semakin wilayah yang dikelola dengan tidak memperhatikan infrastruktur tranportasi yang baik makan otomatis daerah tersebut akan mengalami kemunduran dari sisi produktivitas barang atau jasa yang dihasilkan. Pengelolaan RTRW merupakan salah satu langkah mengefisienkan dan mengefektifkan semua aktivitas menjadi lebih baik. Kebijakan yang dilakukan pemerintah sudah tetap dengan menyatukan semua kempentingan dalam pengelolaan RTRW dalam satu sistem 
pengelolaan wilayah secara nasional. Namun apakah ini bisa terlaksanaan dengan banyaknya kempentingan dan hambatan disemua wilayah di Indonesia.

\section{METODE}

Analisis pada penelitian ini menggunakan pendekatan desain penelitian deskriptif (descriptive research) yaitu prosedur penelitian yang menghasilkan data desriptif berupa katakata tertulis dari orang-orang dan perilaku yang diamati, didukung dengan studi literature atau studi kepustakaan berdasarkan pendalaman kajian pustaka, berupa data dan angka, serta mempelajari dan mengelaborasi aturan, dan fakta actual terkait dengan Paket VIII Kebijakan Ekonomi Pembangunan Dengan Satu Pemanfaatan Ruang dan Penggunaan Lahan di Indonesia dengan tujuan menginformasikan kepada pembaca (informative research).

\section{HASIL DAN PEMBAHASAN}

\section{Data dan fakta}

Perubahan pengunaan lahan dianalisis berdasarkan peta penggunaan lahan dari tahun 2001 hingga 2008. Berdasarkan analisis tersebut diketahui terjadi beberapa perubahan pemanfaatan ruang. Data tabel 1 berkaitan penggunaan lahan dapat menjadi gambaran penggunaan RTRW di Indonesia.

Tabel.1 Nilai Perubahan Luas Penggunaan LahanTahun 2001-2008

\begin{tabular}{|c|c|c|c|c|c|c|}
\hline Jenis Lahan & Luas 2001 (Ha) & \% Luas 2001 & Luas 2008 (Ha) & \% Luas 2008 & Perubahan (Ha) & \% Perubahan \\
\hline Sawah & 540,66 & 2.8 & 395,28 & 2.1 & -145.39 & -0.8 \\
\hline Hutan & 2804,69 & 14.6 & 1550,00 & 8 & -1245.69 & -6.5 \\
\hline Ladang & 6028,67 & 31.3 & 8392,17 & 43.6 & 2363.5 & 12.3 \\
\hline Pemukiman & 3682,29 & 19.1 & 3993.73 & 20.7 & 311.44 & 1.6 \\
\hline Perkebunan & 6198,65 & 32.2 & 4923,78 & 25.6 & -1274.87 & -6.6 \\
\hline
\end{tabular}

Sumber: Penelitian Rizka dan Hilda, 2014

Perubahan pengunaan lahan dipengaruhi oleh aktivitas manusia oleh sebab itu diperlukan evaluasi fungsi pengunaan lahan demi menjaga fungsi dasar lahan yang dimilik oleh setiap wilayah agar tidak terjadi tumpang tindih kepentingan demi menjaga tujuan yang akan dicapai oleh Indonesia secara keseluruhan.

Meningkatnya jumlah penduduk suatu wilayah khususnya kota secara alamiah disertaiderasnya arus urbanisasi, yang memerlukan bertambahnya penyediaantempat bermukim dan meningkatnya mobilitas yang memerlukanbertambahnya penyediaan sarana transportasi, menyebabkan makinterbatasnya ruang tanah yang tersedia untuk memenuhi kebutuhanmasyarakat perkotaan yang beraneka ragam. Dengan demikian tanahbukan hanya penting untuk pertanian, tetapi juga untuk lain-lainpembangunan yang memerlukannya. Sedangkan tata guna tanah ada beberapa pengertian yang asasi yaitu: koordinasi yang berkembang, ialah masalah benda-benda tetap registrasi, peruntukan, pengaturan, pengusahaan, pengelolaan, pemakaian, perpajakan, pemerintahan dan peradilan.

Tanpa suatu pendaftaran tanah sebagai registrasi dari keadaan hukum dari benda tak bergerak, maka bentuk-bentuk dari penatagunaan tanah adalah merupakan suatu yang mutlak tidak dapat dibayangkan, sebab tidak akan bisa membuat suatu rencana, tanah mempunyai suatu sistem informasi, baik pada operasinya, sehingga tidaklah masuk akal bila mengatur sesuatu tetapi tidak mengetahui suatu hak atas tanahtersebut secara luas.Untuk sampai pada suatu perencanaan yang matang guna pengembangan tata guna tanah, sangatlah sulit, sebab banyak kendala-kendala yang harus diatasi terlebih dahulu. Kendala-kendala tersebut antara lain ialah: 
1. keterpaduan antara instansi sulit dilaksanakan,

2. tidak meratanya penduduk di seluruh Indonesia, terutama di pulaupulau tertentu, sehingga tidak mungkin penerapan yang seragam dari tata guna tanah,

3. berbagai produk hukum yang meninjau dari suatu proyek yang berlainan solusinya,

4. belum adanya daftar yang mantap atas seluruh aset yang ada, misalnya, hak-hak atas tanah yang ada, jenis-jenis hak, kemampuan dari tanah-tanah tersebut penggunaannya masih belumtertib,

5. masih banyak penggunaan tanah secara tidak beraturan, adanya industri di daerah pemukiman,

6. keterkaitan antara perpajakan dengan pemukiman yang belum terbina dengan baik. Di satu pihak perpajakan berusaha mendapatkan pajak yang sebanyak banyaknya, disisi lain, masyarakat golongan menengah ke bawah tidak dapat membayar pajak sebagai akibat dari inflasi dan penurunan nilai mata uang yang mereka terima,

7. perkembangan industri yang mempergunakan tanah-tanah pertanian yang subur dan berdampak mengganggu keswasembadaan pangan nasional, termasuk dalam hal ini industri pariwisata dan pemukiman mewah yang mempergunakan tanah-tanah yang seyogyanya sebagai wadah penampungan air dan sebagaitempat resapan air.

Hal-hal tersebut di atas masih sulit sekali mengatasinya. Menurutpasal 14 dan 15 UUPA, sebenarnya telah berusaha untuk menciptakan suatu Peraturan Pemerintah tentang Penatagunaan tanah, namun sampai sekarang belum terealisir, masih merupakan harapan saja (Lany,1999:1732).

\section{Evaluasi dan dampak}

Dalam pembangunan memperhatikan lokasi, tanah yang akan digunakan harus sesuai dengan peruntukannya. Wilayah dalam kawasan dengan memperhatikan fungsi utama agar dapat melindungi kelestarian hidup. Sebab sejak adanya UULH (Undang-Undang Lingkungan Hidup) masalah pentatagunaan tanah dikembangkan dalam kaitannya dengan penataan ruang dan perencanaan tata ruang. Dengan adanya perencanaan tata ruang, akan menghasilkan rencana teknik ruang, yang dapat menunjukkan kemampuan peruntukan ruang kepada pemerintah dan masyarakat setempat. Hal ini penting dalam kaitannya dengan pemberian izin untuk pembangunan baik untuk pertaniah hingga diperuntukan bagi industri dan operasionalnya. Tentunya setelah mengadakan studi kelayakan, dan harus berasaskan kepada pemanfaatan ruang bagi semua kepentingan secara terpadu, berdaya guna dan berhasil guna serasi, seimbang dan berkelanjutan. Adanya sifat keterbukaan, persamaan, keadilan dan perlindungan. Untuk penetapan dan pelaksanaan tata ruang, harus disertai dengan Analisis Dampak Lingkungan (AMDAL), agar rencana usaha atau kegiatan akan mudah mengetahui sampai dimana beban yang harus ditanggungnya terhadap lingkungan sebagai rencana sesuai yang dimaksudkan. Sehingga tidak merusak lingkungan dan pencemaran lingkungan sesuai yang diamanatkan dalam UUD 1945.

Tingkat manfaat tata guna tanah dan tata ruang sangat tergantung pada pemanfaatan sumber daya alam yang tersedia, dan sumber daya manusianya. Dalam era global ini tata guna tanah dan tata ruang secara nasional tidak bisa dipisahkan, satu dengan yang lain saling berkaitan dan perlu dikembangkan dengan merujuk pada peraturan-peraturan di negara lain yang menyangkut tata guna tanah dan tata ruang, sebagai perbandingan. Sehingga perspektif masa depan harus telah direncanakan dan dipersiapkan secara matang.

\section{a. Kelembagaan}

Pengelolaan Tata ruang sesuai dengan kebijakan "Paket VIII Ekonomi Pemabangunan" melalui Koordinasi Kementrian Bidang Ekonomi bahwa perencanaan wilayah tetap berada ditangan Badan Perencanaan Pembangunan Nasional (BPPN) dan berkoordinasi dengan kementrian terkait dan setingkat kementrian seperti BPN (Badan 
Pertanahan Nasional). Semua kegiatan dalam pengelolaan tata ruan tetap menjadi tanggung jawab semua pihak yang terkait baik di tingkat pusat dan daerah.

\section{b. Tujuan}

Tujuan mengelurkan kebijakan ini untuk mempercepat pelaksanaan pembangunan nasional dan memberikan kepastian usaha bagi para investor untuk menanamkan investasinya di Indonesia. Mempermudah dan mempercepat penyelesaian konflik tumpang tindih permanfaatan lahan, penyelesaian batas antar wilayah di Indonesia.

\section{c. Cakupan}

Kebijakan ini mencakup seluruh wilayah di Indonesia dengan mengedepankan kepentingan bersama diatas segalanya. Kearifan lokal menjadi pondasi demi mencapai tujuan nasional yaitu mensehjahtrakan kehidupan bangsa Indoensia berlandaskan UUD 1945.

\section{d. Target Kebijakan}

Pelaksanaan secara menyeluruh penetapan pengelolaan RTRW ditangetkan selesai dan digunakan secara nasional pada tahun 2019. Namun terget paling lambat adalah tahun 2025 .

\section{KESIMPULAN DAN SARAN}

\section{Kesimpulan}

Kebijakan di bidang pegembangan tata kelola wilayah akan berkaitan dengan RTRW tingkat nasional serta pengawasannya. Berkaitan permasalahan yang terjadi dari mulai tingkat daerah hingga tingkat pusat atau lebih familinnya tingkat pertkotaan merupakan masalah yang kursial sulit untuk diselesaikan dengan waktu yang sangat singkat. Walaupun pemerintah telah merilis kebijakan ekonomi melalui "Paket VIII" yang telah dikeluarkan melalui Menko Bidang Ekonomi rasanya sulit bisa terhujud dengan pengunaan satu peta wilayah nasional. PersepsiMasyarakat Terhadap Rencana Pemanfaatan Ruang Wilayah KotaPemanfaatan ruang berbagai fungsi baik fungsi primer maupun skunder terusmengalami peningkatan.

Kebijakan yang telah dijalankan oleh pemerintahdaerah dibidang pemgembangan kota, fungsi kota, kependudukan, fungsiruang dan pengembangan fasilitas umum perlu dipertahankan, sedangkankebijakandi bidang pembangunan berbagai sektor perlu dikaji kembali danpenyususnanya perlu melibatkan masyarakat melalui peningkatan informasi komunikasi sosialisasi, penyuluhan, penataan, sertapengawasan.

\section{Saran}

Kebijakan pembangunan RTRW atau tata kelola wilayah harus dirumuskan bersama antara pemerintah pusat dan daerah agar tujuan dapat tercapai. Tumpang tindih kebijakan harus segera diselasaikan khususnya di daerah, sebab kebijakan otonomi daerah memberikan peranan yang lebih kepada perintah daerah untuk mengatur wilayahnya.

Pembangunan sektor ekonomi harus lebih diperhatikan dalam kebijakan otonomi daerah, baik dari pelayanan pengurusan ijin usaha hingga pemberian ruang kepada investor yang masuk ke Indonesia. 


\section{DAFTAR PUSTAKA}

Aminah, Siti.2015. Konflik dan Kontestasi Penataan Ruang Kota Surabaya.Jurnal LabSosio.Vol.20. No (1). Hal;59-79.

Asnar, Habibie Zaid.2013. Pengaruh Tata Ruang Kantor Terhadap Produktivitas Kerja Pegawai Di Pusat Kajian Dan Pendidikan Dan Pelatihan Aparatur III Lembaga Administrasi Negara (PKP2A III LAN) SAMARINDA.eJournal Ilmu Pemerintahan.Vol.1. No (4). Hal:14881500.

Boru, Jeky El.2013.Analisis Pengaruh Pembangunan Jalan Layang Janti Terhadap Perkembangan Tata Ruang Kawasan Janti (Studi Kasus: Kawasan Janti, Desa Catur Tunggal, Kabupaten Sleman). Jurnal Arsitektur Komposisi.Vol.10. No (4).Hal:255-266.

Kusumawati, Lany.1999. Tata Guna Tanah Konvensional Terhadap Perkembangan HUkum Tata Ruang Pada Pembangunan Industri PULP Dan Paper.Jurnal Unitas.Vol.7.No(2).Hal:17-32.

Lubis, Suardi., Suprayogi, Andri, dan Hani'ah. 2013. Keseuaian Rencana Tata Ruang Wilayah (RTRW) Dengan Penggunaan Lahan Kecamatan Gayamsari dan Kecamatan Semarang Timur.Jurnal Geodesi Undip.Vol.2. No (2). Hal:13-22.

Maria, Rizka.,dan Lestiana,Hilda.2014.Pengaruh Penggunaan Lahan Terhadap Fungsi Konveservasi Air Tanah Di Sub Das Cikapung.Jurnal Ris.Geo.Tam.vol.24.No(2).Hal:7789.

Nugroho, Prihadi., dan Sugiri, Agung.2009. Studi Kebijakan Pembangunan Terhadap Perubahan Tata Ruang Di Kota Semarang.Jurnal Riptek.Vol.3.No(2).Hal:41-51.

Najmulmunir, Nandang.2013. Pengaruh Partisipasi Masyarakat Terhadap Efektifitas Implementasi Rencana Tata Ruang Wilayah Kabupaten Bekasi.Jurnal Manusia dan Lingkungan.Vol.20. No (2). Hal:213-220.

Suhariyanto. Didik. 2009. Peranan Pemerintah Daerah Serta Masyarakat Dalam Perencanaan Dan Pelaksanaan Penataan Ruang Menuju Perspektif Pertumbuhan Kota Banyuwangi.Jurnal ILmiah Progressif.Vol.6. No (18). Hal:1-10

Tusin, Gammaria Gumayani. 2004. Pengaruh Kebijakan Politik Pembangunan Terhadap Tata Ruang Kota (Studi Kasus: Kota Jakarta). Jurnal NALARs.Vol.3.No(3).Hal:46-59. 